\title{
Demographic Issues in Malaysia
}

\author{
Nik Norliati Fitri Md Nor ${ }^{1}$ \\ ${ }^{1}$ Geography Section, School of Distance Education, Universiti Sains Malaysia, Malaysia \\ Correspondence: Nik Norliati Fitri Md Nor. E-mail: nikfitri@usm.my
}

Received: December 13, 2018

doi:10.5539/ass.v15n11p116
Accepted: April 3, $2019 \quad$ Online Published: October 26, 2019

URL: https://doi.org/10.5539/ass.v15n11p116

\begin{abstract}
This article will discussed about demographic issues in Malaysia and focused about fertility trend, increasing the number of ageing (60 years and above) and non citizen residents. Since 2016 years the crude birth rate in Malaysia are decreased to 16.6 per 1000 population compared to 18.5 per 1000 population in 2009 . Starting on years 2019, fertility trend among women are decreased which is below the replacement level 2.1 child per women (15-49 years reproductive women) especially Chinese and Indian ethnic. In 2014, Chinese ethnic and Indian showed that total fertility rate is 1.4 child per women. In 2015, Malay ethnic showed the total fertility rate is 2.6 per child among women 15- 49 years. This situation showed the issued of age population increasingly significantly. The percentage of older person in Malaysia in 2010 among Chinese, Indian, Malay and Bumiputera ethnic are representively 12.2 percent, 7.9 percent, 7.3 percent and 6.2 percent. It showed that the issues of social support for example the living arrangement of older persons, health care, health status and income are the most important issues and must be addressed. Besides that, Malaysia will be challenging problem migrant worker from Asian country and will cause the problem for example for Malaysian citizen to get the work. Based on Department of Statistics Malaysia in 2016, there are about 3.3 million non-Malaysian citizens in Malaysia which is 80.3 percent in 15-64 years. Hopefully this paper will provide some suggestions to enable the authorities to address these issues more effectively.
\end{abstract}

Keywords: Malaysia, fertility, ageing population, internal migration

\section{Introduction}

There are three factors that caused to the changes in the world demographic profile which are economic development, health care improvement and decreasing the numbers of fertility rates. The changes however differ between the developed and developing countries. The former usually have higher older population in comparison to the latter.

As the industrial revolution in Europe the world's growth rates have declined because of declining birth rates, the growing number of elder peoples and the inundation of foreign workers by permission and without permission. The low fertility rate, the increase in the elderly and the influx of foreigners is a global issue that needs to be addressed and should be taken seriously by the authorities. The methodology for this study means to adopt the use of secondary data census population, data from the Department of Statistics Malaysia and other related documents. This paper will look into the details of the three issues raised to evaluate and interpret the extent to which the decline in fertility, aging population and illegal immigrants in Malaysia could have an impact on the country.

Like any other countries around the world, Malaysia is also experienced a rapid growth of the older population. This is a direct consequence of the decades of socio-economic development and public health policies where falling fertility and rising longevity have resulted in the rise of new generations. The question is, what is the situation of population ageing in Malaysia? What can be done to address population ageing issues? This paper provides an overview of population ageing issues and challenges in Malaysia. It will focus on the trends of population ageing and the characteristics of the elderly in Malaysia. The discussion of the prospects and the way forward for population ageing in Malaysia is also discussed. Data from previous publications will be utilized and updated throughout the paper.

To understand the development and significance of ageing issues, the context it occurs is important. Many researchers have described the population and characteristics of Malaysia, tracing back from her pre-Independence days to the modern Malaysia (Caldwell, 1962). The foundation and forces which shaped the 
population since the colonial days, in many ways, have perpetuated till this day.

The distribution of the aged population within geographical locations aligns with the historical development of the nation. Our multi-racial and multicultural society gives rise to significant diversity in the Malaysian ageing experience and some issues may be strange to specific ethnic communities.

This section describes the basic indicators of population ageing that is commonly used to understand the worldwide phenomenon. This involved the use of the population pyramid which is to measure the location (median age) and head count ratios (dependency and ageing index). The pyramid is the graphic representation of the age-sex distribution with definitive shape to reflect population structure.

\section{Fertility Trend in Malaysia}

Malaysia has achieved independence since 1957 and in the early 1960s the gross birth rate was 38.1 per 1000 population (1963). Until 1985, the gross birth rate of the population was 31.5 per 1000 population (Table 1). However in 2009, the gross birth rate in Malaysia has dropped to 18.5 per 1000 population, while its fertility rate is 2.3 children per women. This means that women aged 15-49 have two to three children. What is alarming is that the rate of total fertility in Malaysia is currently at the level of replacement of 2.1 children per women. It coincides with the study of Mauldin and Ross (1994) which expects the fertility rate of Malaysian population to reach a replacement level of 2.1 children per women by 2015 . Accordingly, the 70 million Population policy recommended by Tun Dr Mahathir Mohammad in 1982 is necessary is considered and applied in a society of four to five children compared to two children today (The Ad-hoc Committee on Population Issues, 1984).

The declining fertility rate in Malaysia or anywhere else is significantly associated with the increase in the first marriage age among women. The problem or problem is not to be married or married, but it affects demographic problems when not giving birth. According to Caldwell (1997), the first marriage age minus is said to be the most important catalyst in population change in Asian countries when it results in fertility decline. According to a study conducted by the Department of Statistics, Malaysia (2011), found that Malaysia's first marital life mean of 2010 was 27.3 years, 25.7 years for women, while 28.0 years for males. It shows the increase in the mean age of the first marriage in 2010 compared to 23.4 years in 1970 (Department of Statistics Malaysia, 1977).

The decline in fertility in Malaysia has been associated with a decline in gross mortality and a decrease in infant mortality rates. In Malaysia, the gross mortality rate in 2010 has decreased to 4.8 per 1000 population compared to 8.5 per 1000 population in 1963. According to Usman Haji Yaakob (2008) the infant mortality rate refers to the death of a one-year-old child. The rate of infant mortality in Malaysia showed between 1963 and 2009 showed a decline of 55.5 per 1000 live births in 1963 to 6.9 per 1000 live births in 2010.

Table 1. Crude birth rate, crude mortality rate, total fertility rate, infant mortality rate, life expectancy in Malaysia, 1963-2015

\begin{tabular}{cccccc}
\hline \multirow{2}{*}{ Years } & \multicolumn{2}{c}{ Birth } & \multicolumn{3}{c}{ Mortality } \\
\cline { 2 - 5 } & $\begin{array}{c}\text { Crude Birth Rate (per } \\
\text { 1000 population) }\end{array}$ & $\begin{array}{c}\text { Total Fertility Rate } \\
\text { (child per women) }\end{array}$ & $\begin{array}{c}\text { Crude mortality rate } \\
\text { (per 1000 population) }\end{array}$ & $\begin{array}{c}\text { Infant mortality rate } \\
\text { (per 1000 live birth) }\end{array}$ & $\begin{array}{c}\text { expectancy } \\
\text { (years) }\end{array}$ \\
\hline 1963 & 38.1 & $6.7(1960)$ & 8.5 & 55.5 & 55.7 \\
1965 & 36.1 & 5.9 & 7.5 & 46.6 & 59.4 \\
1970 & 32.4 & 5.2 & 6.7 & 39.4 & 61.6 \\
1975 & 30.7 & 4.2 & 6.0 & 32.2 & 64.3 \\
1980 & 30.6 & 4.2 & 5.3 & 23.8 & 66.4 \\
1985 & 31.5 & 4.0 & 5.0 & 16.4 & 67.7 \\
1990 & 27.9 & 3.6 & 4.6 & 13.1 & 68.9 \\
1995 & 26.8 & 3.4 & 4.7 & 6.3 & 69.1 \\
2000 & 22.6 & 2.9 & 4.5 & 6.6 & 72.3 \\
2005 & 18.5 & 2.4 & 4.5 & $6.9(2009)$ & 74.0 \\
2010 & $18.5(2009)$ & $2.3(2009)$ & 4.8 & 6.4 & 75.0 \\
2015 & 16.7 & 2.0 & 5.0 & 75.6 \\
\hline
\end{tabular}

Source: Department of Statistics Malaysia. (2001: 2003; 2008: 2011; 2016; 2017) and United Nations (2001).

\section{Ageing Population in Malaysia}

Malaysia like other countries can not miss the phenomenon of fertility decline and the increase in age group (60 years and above). According to data published by the Department of Statistics, Malaysia (2017), Malaysia has 
now reached 9.3 percent or 3.0 million aged 60 and above. Based on the United Nations (UN) aging is categorized into three main groups: i) Ageing Society: when the population is 65 and over 7 percent of the population; ii) Aged Society: when the population is 65 and over 14 percent of the population; iii) Super-aged Society: when the population is 65 and over reach 20 percent of the population. Based on National Senior Citizen Policy (MWKM) aging is when the population is 60 years old and more than 15 per cent of the total population (Department of Statistics Malaysia, 2017).

Table 2 shows the population of 60 years and above and the growth rate according to gender in Malaysia in 1970 to 2010 . The table shows that in 1970 the percentage of the elderly was 5.2 per cent and then increased to 7.9 per cent in 2010. The table also showing elderly women was higher than men except in 1970. It was found that the number of senior citizens in 2010,1,105,292 were men, while 1,145,924 were women. Additionally, the table also shows an increase in percentage increase from year to year, for example an increase of 4.5 percent between 2000 and 2010. Figure 1 shows the population pyramid in 1970 and 2010 for Malaysians. The figure shows that there is an expansion and an increase in percentages for seniors 60 years and above, while the percentage of young people 0-14 years is shrinking and shrinking in 2010. These elderly enhancements will bring various socio-economic and political problems to the country and impact on the country increase in elderly health care costs (Tabata, 2005).

One important issue about the elderly is the arrangement of life that is about where the residence and with whom the elderly live. Discussions on the arrangement of elderly people over the place of residence are family support provided to the elderly such as economic support, physical support and emotional support. It is also included in the aspect of social support as well as the financial resources of the elderly to achieve the goal towards their well-being. The arrangement of elderly people or with whom they live is an important component of the well-being of the elderly and is part of family support (Knodel \& Ofstedal, 2002). The pattern of the elderly's life arrangement will give the impression of the quality of life and the well-being of the elderly themselves (Du \& Guo, 2000). Recently, many newspapers talk about the issue of marginalized people especially for those living in rural areas. They often suffer from "Empty Nest" syndrome, which is a sense of silence and sadness of living alone as a distance away from children, especially for those living in rural areas (Abdullah, 2001). Older life expectancy of up to 75 years old should require a specific strategy for a more secure future. Hence, there are many obstacles and challenges that the elderly have to take to compete for a comfortable place in their old days.

Table 2. Total population aged 60 years and over and the rate of growth of the elderly by sex in Malaysia, 1970-2010.

\begin{tabular}{|c|c|c|c|c|c|c|c|c|}
\hline \multirow{2}{*}{ Years } & \multirow{2}{*}{$\begin{array}{c}\text { Total of } \\
\text { Population }\end{array}$} & \multirow{2}{*}{$\begin{array}{l}\text { Total of Ageing } \\
\text { Population ( } 60 \\
\text { years and above) }\end{array}$} & \multirow{2}{*}{$\begin{array}{c}\text { Percent } \\
(\%)\end{array}$} & \multicolumn{2}{|c|}{ Gender } & \multicolumn{3}{|c|}{ Increasing of Ageing Population } \\
\hline & & & & Man & Women & & & \\
\hline 1970 & $10,439,430$ & 546,020 & 5.2 & 284,753 & 261,267 & Years & Numbers & Percent $(\%)$ \\
\hline 1980 & $13,136,109$ & 745,190 & 5.7 & 368,034 & 377,156 & 1970-1980 & 199,170 & 3.2 \\
\hline 1991 & $18,379,655$ & $1,068,531$ & 5.8 & 505,284 & 563,247 & 1980-1991 & 323,341 & 3.3 \\
\hline 2000 & $23,274,690$ & $1,451,665$ & 6.2 & 693,124 & 758,541 & $1991-2000$ & 383,134 & 3.5 \\
\hline 2010 & $28,334,135$ & $2,251,216$ & 7.9 & $1,105,292$ & $1,145,924$ & $2000-2010$ & 799,551 & 4.5 \\
\hline
\end{tabular}

Source: Department of Statistic Malaysia. (1973; 1984; 1995; 2001a; 2011).

\section{International Migration in Malaysia}

Malaysia's solid economic growth and extensive employment opportunities have pulled in more foreign workers to come to Malaysia. They venture into various fields of work such as construction, plantation, retailing, manufacturing and others. Developed countries like Malaysia are likewise in need of foreign workers, especially in jobs that are not in demand by local workers. Not surprisingly, the international migration of people from Myanmar, Indonesia, Bangladesh, India, China and so on. International migration is a movement of people who come in and out from to Malaysia (Department of Statistics Malaysia, 2017). This means that international migration only involves the change of non-Malaysian citizens only. Statistics published by the Department of Statistics, Malaysia (2017a) show that 1 out of 10 residents is non-citizens with a total of 3.3 million non-citizens. The statistics are based on data obtained from the Immigration Department of Malaysia, the Ministry of Higher Education and the National Registration Department and refer to non-residents living in Malaysia for six months or more during the reference year. Overall, the percentage of international migration (migration) in the 2010 Census (period 2005-2010) increased to 1.7 percent $(468,025$ persons) compared to 1.5 percent $(331,971$ persons) 
in the 2000 Census. Migrants from Indonesia dominated international migration with 51.7 percent 2014) (Department of Statistics Malaysia, 2017).
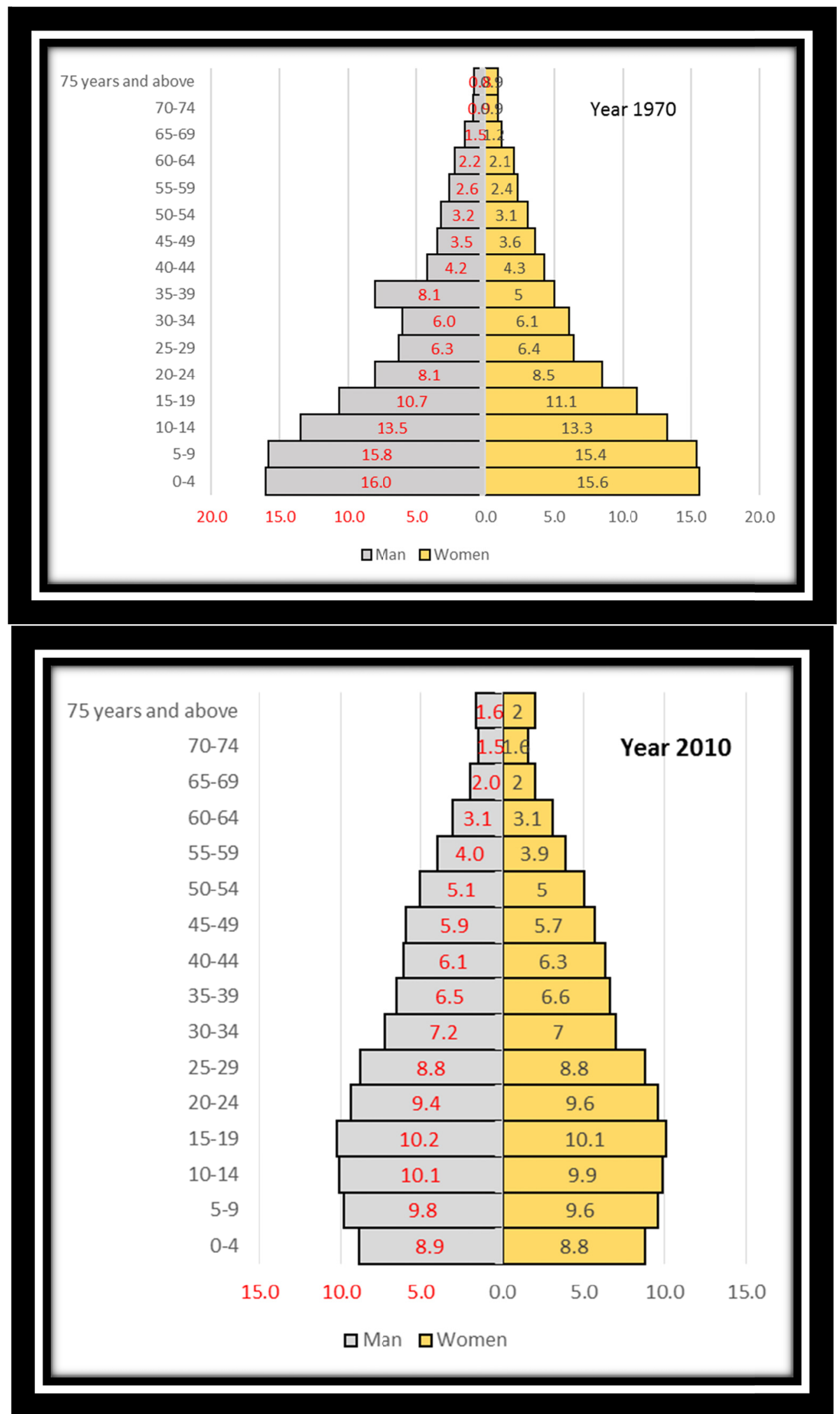

Graph 1: Comparison of percentage of population in Malaysia for year 1970 and 2010. 
Table 3 shows the characteristics of non-Malaysian citizens in Malaysia from 1991 to 2010. Table 3 shows an increase in the number of foreigners, an increase of more than 200 percent, respectively, of 751,113 (1991) to 2,320,779 in 2010. Moreover, men were higher than women is 439,395 (men), while 311,718 (women) in 1991, as well as in subsequent years. For the non-citizen category by age, the highest group of 15 to 64 years was 76.5 percent in 1991 and increased to 80.3 percent in 2010. In view of the distribution of non-citizen residents, it was observed that more people living in urban areas than those who live in rural areas. For example, the percentage of non-residents in urban areas in 2010 was 65.4 percent while only 34.6 percent of non-resident living in rural areas.

According to Dupont (1997), the uncontrolled international migration movement will bring about various national security issues and will bring about various social, economic and political issues. Examples of citizenship status or citizenship status, minimum wage rights, health services, education funding to immigrant children and so on. Since then, numerous problems have been caused by foreigners, especially criminal cases such as home-based breakdowns, social networking scams, robbery cases and murders. According to Mohd Bakri Zinin, Bukit Aman's Criminal Investigation Department Director (JSJ) said most of the burial cases that occurred during the festive season in the country were masterminded by foreigners (Berita Harian, 2012). Statistics also show that home-burial cases are more popular among foreigners than locals.

Table 3. Characteristics of non-Malaysian citizens, 1991-2010

\begin{tabular}{cccccccccc}
\hline & \multicolumn{3}{c}{ Population } & \multicolumn{3}{c}{ Age Group (years) } & \multicolumn{2}{c}{ Urban Areas } & Sex ratio (number of \\
\cline { 2 - 8 } Years & Total & Man & Women & $0-14$ & $15-64$ & $\begin{array}{c}\text { 65 years and } \\
\text { above }\end{array}$ & $\%$ & Number & men 100 women \\
\hline 1991 & 751,113 & 439,395 & 311,718 & 21.9 & 76.5 & 1.6 & 42.0 & 315,637 & 140.9 \\
2000 & $1,384,774$ & 780,354 & 604,420 & 19.0 & 79.0 & 2.0 & 58.9 & 816,455 & 129.1 \\
2010 & $2,320,779$ & $1,386,369$ & 934,410 & 17.8 & 80.3 & 1.9 & 65.4 & $1,518,077$ & 137.3 \\
\hline
\end{tabular}

Source: Department of Statistic Malaysia. (1995; 2001a; 2011a).

The amount of non-citizens is also likely to rise in the future and fears that it will threaten local residents to get jobs. The influx of foreign workers has reached a critical level that endangers national security. To address this issue, the government has launched a 6P (Registration, Bleach, Monitoring, Enforcement, Forgery and Deportation) program, with 2,320,034 foreign workers and foreigners registered with the $6 \mathrm{P}$ program ending February 15, 2012 and out of this total 1,016,908 foreign workers valid and 1,303,126 are PATI (KOSMO, 2011). However, there are still illegal immigrants who have not been enrolled in the $6 \mathrm{P}$ program. In addressing the issue of foreign workers there are three important aspects that need to be addressed. The first aspect is on the distribution and status of legal workers or PATI, both the citizenship identity and the third strategic management covering the welfare, protection, employment, medical facilities and other basic amenities required.

\section{Conclusion}

Basically, this paper discussed three major issues, namely the declining birth rate, an increase in the number of elderly and the growing number of non-citizens. Malaysia is expected to obtain a total fertility rate of 2.1 children by 2015 and this rate will continue to decline in the future. Countries with low long-term fertility will face various problems related to the reduction in the number of young people and it will affect the number of human resources. This situation will undoubtedly affect the human resource development program and is likely to continue to depend on foreign labor in the future. Dependence on foreign labor is increasingly significant in Asia Pacific countries such as Japan, Singapore, the Republic of Korea, Taiwan and Hong Kong. All of these countries have long reached fertility rates below the level of replacement. Malaysia is also no exception depending on foreign labor for a particular job field.

It is indisputable that Malaysia still needs foreign workers, especially the jobs that local workers are interested in. Nevertheless, the dependence on unskilled foreign workers will inhibit Malaysia's desire to shift to high value-added economic activity. Therefore, Malaysia should revive the 70 Million Population Policy recommended by Tun Dr. Mahathir Muhammad in 1982. If this low fertility problem continues, it will create various issues related to the lack of a young workforce, dependence on foreign labor and consequently increase the number of elderly. The increase in the elderly will certainly lead to numerous problems including neglect, silence, poverty, stress, and depression.

\section{Acknowledgement}

The authors would like to thank Universiti Sains Malaysia for funding this project through Short Term Grant 


\section{(304/PJJAUH/6315265).}

\section{References}

(2010). World Population Ageing 2009. New York.

Abdullah, F. (2001). Empty Nest: Satu Penelitian Keluarga di Tahap Ahkir dalam Edaran Hidup. In A. A. Jemain, L. Z. Mohamad, \& W. N. Mohamed (Eds.), Jaminan Sosial Warga Tua (pp. 51-62). Selangor: Prentice Hall.

Caldwell, J. C., \& Caldwell, B. K. (1997). Asia Demographic Transition. Asian Development Review, 15(1), 52-87.

Department of Statistic Malaysia. (1973). Age Distribution. Kuala Lumpur.

Department of Statistic Malaysia. (1977). General report 1970. Kuala Lumpur.

Department of Statistic Malaysia. (1984). Population Report for Administrative District. Kuala Lumpur.

Department of Statistic Malaysia. (1995). General Report of the Population Census Vol 2. Kuala Lumpur.

Department of Statistic Malaysia. (2001). Vital Statistics Time Series 1963-1998. Kuala Lumpur.

Department of Statistic Malaysia. (2001a). Population Distribution and Basic Demographic Chracteristics. Kuala Lumpur.

Department of Statistic Malaysia. (2003). Vital Statistics Malaysia 2003. Kuala Lumpur.

Department of Statistic Malaysia. (2008). Vital Statistics Malaysia 2007. Kuala Lumpur.

Department of Statistic Malaysia. (2011). Vital Statistics Malaysia 2010. Putrajaya.

Department of Statistic Malaysia. (2011a). Population Distribution and Basic Demographic Chracteristics 2010. Putrajaya.

Department of Statistic Malaysia. (2014). Migration and Population Distribution 2010. Putrajaya.

Department of Statistic Malaysia. (2016). Vital Statistics Malaysia 2015. Putrajaya.

Department of Statistic Malaysia. (2017). Abridged Life Tables Malaysia 2015-2017. Putrajaya.

Department of Statistic Malaysia. (2017a). Current Population Estimates 2017. Putrajaya.

Department of Statistic Malaysia. (2017b). Migration Survey Report Malaysia 2016. Putrajaya.

Dupont, A. (1997). Unregulated Population Flows in East Asia: A New Security. Pacifica Review, 9(1), 1-22.

Mauldin, W. P., \& Ross, J. A. (1994). Prospects and Programs for Fertility Reduction, 1990-2015. Studies in Family Planning, 25(2), 77-94.

Muda, W. A. M. W. (1991). The Seventy Million Population Policy: Implications on Health, Nutrition and Aging. In M. I. Said, \& J. Saravanamuttu (Eds.), Images of Malaysia (pp. 224-261). Kuala Lumpur: Persatuan Sains Sosial Malaysia.

Pala, J. (2005). Population Ageing Trends in Malaysia. Kuala Lumpur.

The Ad-hoc Committee on Population Issues. (1984). 70 Population Policy Malaysia: Towards a Population of Seventy Million. Malaysia: National Population \& Family Development Board Malaysia.

United Nations. (2001). World Population Prospects, 1, 312-313.

Yaakob, U. H. (2008). Kesihatan dan Kematian Bayi di Kedah. Pulau Pinang: Universiti Sains Malaysia.

\section{Copyrights}

Copyright for this article is retained by the author(s), with first publication rights granted to the journal.

This is an open-access article distributed under the terms and conditions of the Creative Commons Attribution license (http://creativecommons.org/licenses/by/4.0/). 